\title{
Pengembangan Keterampilan Menulis Siswa SMAN 1 Semaka Melalui Web Sekolah
}

\section{Suprayogi Suprayogi ', Budi Eko Pranoto 2, Arief Budiman 3, Bagas Maulana ${ }^{4}$, Galuh Budi Swastika ${ }^{5}$}

1, 2, 3, 4, 5, Universitas Teknokrat Indonesia

${ }^{1}$ suprayogi@teknokrat.ac.id; ${ }^{2}$ budiekopranoto@teknokrat.ac.id;

3 arief.budiman10@teknokrat.ac.id

\begin{abstract}
Abstrak
Pengabdian ini bertujuan untuk meningkatkan keterampilan menulis artikel ilmiah populer siswa kelas XI SMA Negeri 1 Semaka. Kegiatan ini dilaksanakan dengan metode kualitatif melalui pendekatan institusional dan pendekatan partisipatif. Peserta dalam kegiatan ini adalah siswa SMAN 1 Semaka kelas XI yang berjumlah 30 siswa. Terdapat dua kali pengambilan data, yang pertama adalah pre-test (sebelum pelatihan menulis ilmiah popular diberikan) dan post-test (setelah pelatihan menulis ilmiah popular diberikan). Pada tahap analisis, data dioleh secara kuantitif dan dijabarkan secara kualitatif. Berdasarkan hasil analisis, temuan menunjukkan bahwa pengombinasian antara pendekatan Content Language Intergrated Learning (CLIL) dan media website sekolah efektif meningkatkan keterampilan menulis ilmiah popular siswa kelas XI SMAN 1 Semaka.
\end{abstract}

Kata Kunci: blog, CILL, digital, keterampilan menulis

\section{Pendahuluan}

Dinamika dalam ranah pengajaran, baik dalam konteks metode dan keberagaman kondisi pemelajar, menyebabkan kebutuhan akan ketersediaan pembaharuan terhadap aspek pedagogis. Langkah tersebut ditempuh untuk merengkuh perhatian pemelajar, agar tujuan kegiatan belajar mengajar tercapai (Pranoto, \& Suprayogi, 2020; Faharani \& Abdollahi, 2018; Hibatullah \& Ardhillah, 2019). Hal ini juga merupakan tuntutan dari perkembangan ilmu pengetahuan dan teknologi yang berimbas pada perkembangan cara berfikir manusia (Sari et al, 2017:18). Proses yang menjadi wadah aktivitas tersebut adalah proses belajar mengajar. Proses belajar mengajar adalah aktivitas yang dilakukan oleh pengajar dengan cara melibatkan pemelajar sebagai objeknya. Proses belajar mengajar tersebut dapat diartikan sebagai proses interaksi berbentuk komunikasi yang dilaksanakan untuk mencapai tujuan dalam belajar yaitu keberhasilan (Ansoriyah, 2020:48). Salah satu tujuan penting dari pembelajaran adalah menghasilkan sosok yang mampu menyampaikan gagasannya, baik lisan maupun tertulis, dengan struktur dan logika yang baik. Kemampuan tersebut sangat lekat dengan kemampuan berbahasa. Menurut Permendikbut No. 24 Tahun 2016 tentang KI dan KD 2013, terdapat empat aspek dalam keterampilan Bahasa, yaitu berbicara, menyimak, membaca, dan menulis (Situmorang, 2018). Meskipun ke-empat komponen tersebut memiliki bobot kepentingan yang sama, akan tetapi kebanyakan perserta didik mengalami kendala 
dalam kemampuan menulis (Zulkarnaini, 2011). Lebih daripada itu, survey terhadap guru Bahasa Indonesia menunjukkan bahwa pelajaran bahasa Indonesia yang paling tidak disukai oleh guru dan siswa adalah pembelajaran menulis. Padahal, kemampuan bahasa adalah salah satu kebutuhan penting dalam industri saat ini (Suprayogi \& Pranoto, 2020)

Keterampilan menulis adalah keterampilan yang harus dikuasai oleh siswa karena berkaitan dengan lengkapnya kemampuan dalam menyusun gagasan, yakni secara lisan dan tertulis (Situmorang, 2018: 166). Banyak ahli telah merumuskan definisi menulis. Keterampilan menulis adalah kemampuan dalam menuliskan gagasan, pendapat, dan perasaan kepada pihak lain (Abbas, 2006:125; Gusti. 2014; Subandi, Satrijono, \& Suhartiningsih, 2014; Candra, 2014). Dalam menuliskan gagasan tersebut, diperlukan keakurasian Bahasa yang digunakan, diksi dan aspek gramatikal lainnya. Sementara itu, Nugroho (2014) menyatakan bahwa menulis tidak dapat hanya dianggap sebagai kegiatan motorik, namun juga merupakan kegiatan yang melibatkan mental, karena menulis merupakan media untuk menyampaikan apa yang dirasakan oleh penulis. Pada akhirnya, menulis merupakan aktifitas berbahasa yang produktif karena dapat menghasilkan produk berupa tulisan yang berisikan hasil pemikiran kreatif, dan kritis (Ayu, 2017; Iskandarwassid \& Ristianti, 2010). Untuk itu, diperlukan metode ajar yang tepat bagi siswa agar memiliki kemampuan menulis yang baik. Pada konteks Sekolah Menengah Atas, pelajaran menulis terintregasi dengan mata pelajaran Bahasa Indonesia, sehingga perlu dilakukan pendekatan praktis untuk meningkatkan keterampilan menulis siswa SMA, salah satunya adalah dengan menitikberatkan pembelajaran Bahasa Indonesia berbasis teks.

Banyak penelitian yang berusaha mengungkapkan implikasi metode pengajaran yang dilaksanakan untuk meningkatkan keterampilan menulis siswa SMA. Ansoriyah (2020) mengkaji pengaruh media blog dengan pendekatan CLIL terhadap kemampuan menulis ilmiah siswa SMAN 13 Jakarta. Hasil penelitian tersebut menunjukkan adanya peningkatan keterampilan menulis teks ilmiah yang signifikan. Sementara itu, Sari, dkk. (2017) menyebutkan keberhasilan penggunaan media blog untuk meningkatkan kemampuan menulis siswa. Efektivitas ini ditunjukkan oleh mayoritas rerata nilai siswa di atas $80(70 \%)$, dan sisanya (30\%) mendapatkan nilai 75 . Lebih lanjut, penelitian yang dilakukan oleh Indawati dan Sumardi (2019) juga ditemukan penggunaan blog efektif meningkatkan keterampilan menulis siswa SMA. Dalam penelitian tersebut, diungkapkan bahwa kelas yang menggunakan media blog (X AK) memperoleh nilai rata-rata lebih besar yaitu 79.33 dibandingkan dengan kelas yang tidak menggunakan media blog (X AP) dengan hasil rata-rata sebesar 58.97. Dapat simpulkan bahwa rata-rata kelas yang medapatkan perlakuan (kelas eksperimen) lebih tinggi dibandingkan dengan kelas kontrol. Dengan demikian, ditemukan korelasi antara penggunaan media blog terhadap keterampilan menulis teks negoisasi.

Menilik kesusksesan pemanfaatan media blog untuk meningkatkan kemampuan menulis siswa, penulis merasa perlu untuk mengadopsi metode tersebut untuk siswa kelas X SMAN 1 Semaka. Di sekolah tersebut, kendala yang dialami oleh siswa dalam proses belajar dapat disebabkan oleh permasalahan yang ada di siswa itu sendiri maupun oleh pengajar yang bersangkutan. Proses pembelajaran Bahasa Indonesia yang dilakukan di SMAN 1 Semaka masih bersifat elementer, akibatnya pembelajaran Bahasa Indonesia akan lebih menarik motivasi siswa, lebih kreatif, lebih inovatif, dan menarik 
minat siswa jika penyampaiannya lebih menarik dengan memanfaatkan fasilitas sebenarnya. Kunjungan dan wawancara tim Pengabdian kepada Masyarakat Universitas Teknokrat Indonesia dengan perangkat sekolah pada bulan Desember 2020, SMAN 1 Semaka masih menghadapi berbagai tantangan dalam penyelenggaraan manajemen berbasis sekolah (MBS), antara lain: 1) terbatasnya fasilitas internet di sekolah 2) belum adanya perencanaan peningkatan kompetensi guru, 3) masih terbatasnya metode mengajar guru, 4) belum adanya website/blog sekolah sebagai sumber informasi, 5) kurangnya keterampilan menulis siswa.

Permasalahan yang menjadi fokus dalam pengabdian ini adalah kurangnya keterampilan menulis siswa. Dengan berkembangnya teknologi informasi saat ini, keterampilan menuangkan dan mengemas gagasan dalam bentuk tulisan yang sederhana merupakan salah satu keterampilan yang krusial. Lebih dari pada it, keterampilan menuangkan gagasan melalui tulisan menjadi salah satu indikator berhasilnya sebuah proses pembelajaran. Untuk siswa, keterampilan menulis menjadi penting karena mampu menggali potensinya untuk menguasai keahlian yang lebih jauh (Sidiq, Pramono, \& Damayanti, 2013). Terlebih, sebagai siswa abad 21, keterampilan menulis seperti ulasan materi, cerita dan kegiatan menjadi keterampilan yang tidak eksklusif untuk jurusan sekolah menengah tertentu melainkan umum yang harus dimiliki dan harus juga diimbagi dengan kemampuan literasi digitalnya.

Dalam proses pelaksanannya, pendekatan Content Language Integrated Learning (CLIL) dengan mengombinasikannya dengan blog/web yang diadobsi dari Asoriyah (2020) digunakan dalam pengabdian ini. Pembelajaran menggunakan CLIL dan media blog memiliki kekhasannya sendiri jika dibandingkan dengan pendekatan lainnya. Oleh karena itu, terdapat aspek-aspek yang perlu dikedepankan dalam penerapannya. Dikutip dari Ansoriyah (2020:49), Coyle menyatakan bahwa dalam menerapkan pendekatan tersebut, yang perlu dikedepankan adalah isi, komunikasi, kognisi, dan budaya. Sementara itu, secara definisi, blog adalah sebuah media dalam jaringan yang dikelola oleh pemakainya untuk menyalurkan gagasan, kreasi, ataupun pendapat dan juga untuk mempublikasikan tulisan yang merupakan hasil pemikiran, pengamatan, dan pengalamannya. Tulisan-tulisan tersebut tidak terikat aturan tertentu namun dibuat dengan menarik untuk menarik minat pembaca. Pemelajar Bahasa dapat memanfaatkan media blog pribadi sebagai wadah untuk menyusun portofolio elektronik yang dapat secara efektif dan efisien dalam menampilkan perkembangan tulisannya dari masa ke masa. Dengan memiliki blog online, mereka juga dapat mendapatkan kesempatan untuk mempublikasikan tulsannya yang dapat dibawa oleh orang lain. Serta juga dapat mendapatkan masukan atau pun kritik atas tulisan tersebut. Menurut guru yang mengjar di SMAN 1 Semaka, kendala yang sering dialami dan bahkan selalu dihadapi oleh guru dan siswa adalah permasalah Bahasa/ kebahasaan yang digunakan siswa dalam menulis. Keterampilan siswa dalam menulis teks artikel ilmiah popular perlu dikembangkan dan ditingkatakan agar menjadi tulisan yang sesuai dengan struktur dan kaidah yang berlaku. Adanya pendekatan pembelajaran dengan materi terkini, diharapkan mampu menyelesaikan kendala yang sering terjadi, sehingga keterampilan menulis siswa dapat meningkat.

Berdasarkan latar belakang tersebut, peneliti mencoba mengembangkan pelatihan menulis teks ilmiah popular dengan pendekatan CLIL dengan memanfaatkan web bagi 
siswa kelas X SMA N 1 Semaka. Pelatihan menulis teks ilmiah popular ini berbentuk workshop pembelajaran yang dilengkapi dengan materi/bahan ajar yang dirancang dan dikemas dengan inovatid dan kreatif yang bertujuan untuk mendukung bahan ajar sehingga dapat menghasilkan variasi belajar selama proses kegiatan belajar mengajar. Berdasarkan elaborasi di atas, dapat dirumuskan bahwa permasalahan dalam pengabdian ini adalah bagaimanakah keefektifan penggunaan pendekatan CLIL dengan media berbasis blog pada menulis teks ilmiah populer. Adapun tujuan penelitian ini adalah mengkaji atau menilai keefektifan penggunaan media pembelajaran berbasis blog pada menulis teks ilmiah populer dalam proses bagi siswa SMA N 1 Semaka.

\section{Metode Pelaksanaan}

Program Pengabdian ini akan dilaksanakan di SMAN 1 Semaka yang beralamat di Jl. Alim Ulama Desa Karang Rejo, Kecamatan Semaka Kabupaten Tanggamus Provinsi Lampung. Pemilihan sekolah ini didasarkan pada kondisi lingkungan yang jarang tersentuh oleh pembangunan serta keadaan sekolah yang membutuhkan fasilitas sumber informasi belajar dan pelatihan pengembangan kompetensi menulis siswa yang kurang terasah karena keterbatasan informasi, kendala jarak serta finansial. Sasaran Program Pengabdian Masyarakat melalui Program Kemitran Masyarakat ini adalah 30 siswa SMAN 1 Semaka. Kegiatan PKM dilaksanakan dalam jangka waktu 4 bulan dengan 3 jumlah kunjungan ke lokasi mitra dan 1 sesi daring.

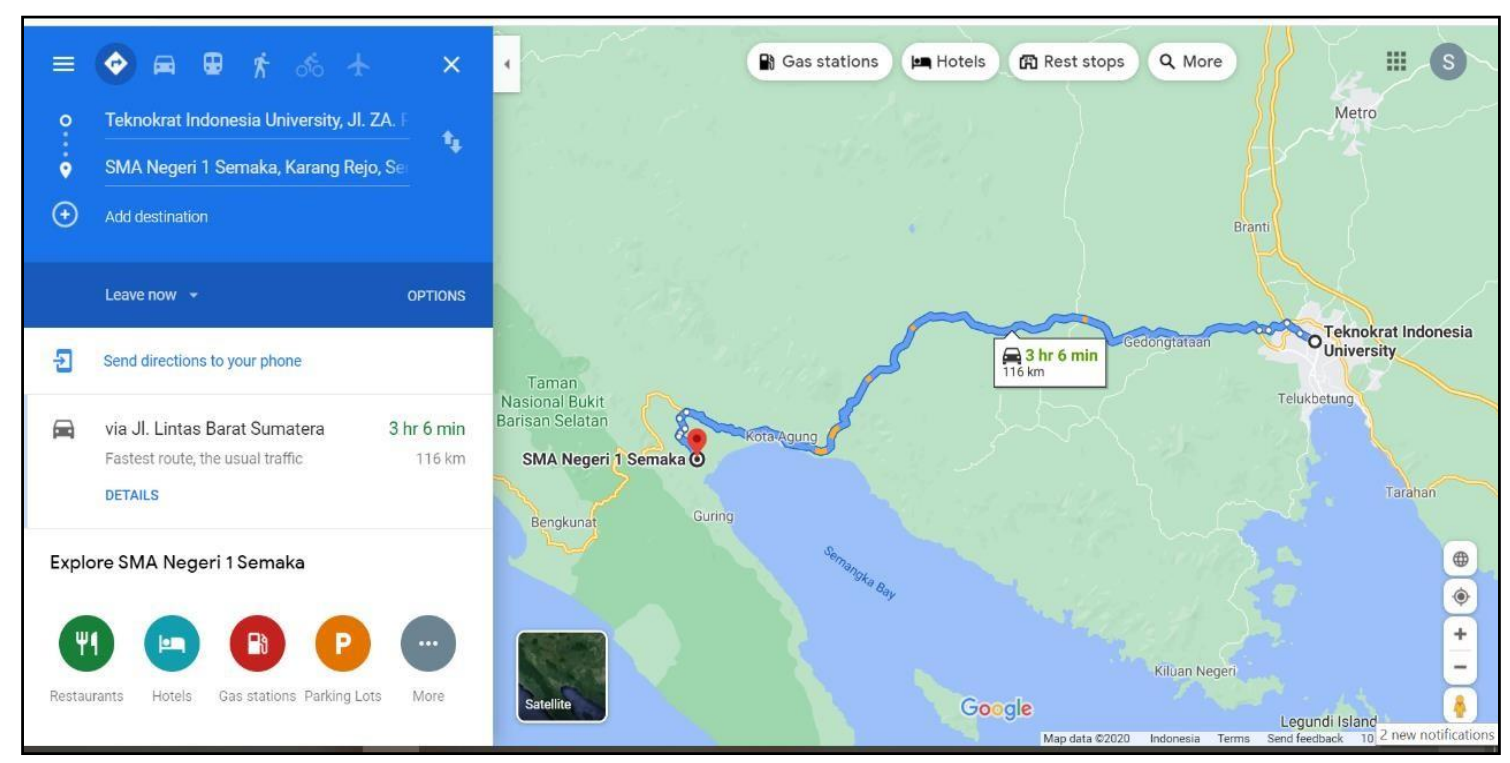

Gambar 1. Peta Lokasi Mitra (SMA Negeri 1 Semaka)

Kegiatan ini dilaksanakan dengan metode kualitatif melalui pendekatan institusional dan pendekatan partisipatif (Moleong, 2018; Cresswell, 2015). Pendekatan institutional dilaksanakan dengan melakukan diskusi bersama mitra untuk memetakan permasalahan-permasalahan terkait penyelenggaraan pendidikan bersama mitra, kemudian melakukan penentuan skala prioritas dari permasalahan yang ada untuk ditindaklanjuti. Bersama mitra kemudian mendiskusikan alternatif solusi yang mungkin dapat direspon oleh tim PKM. Pendekatan partisipatif dilakukan dengan melibatkan 
guru, tenaga kependidikan dan siswa dalam program pelatihan penulisan dan pelatihan pengelolaan website sekolah (www.sman1semaka.sc.id).

Dalam membangun website sekolah, metode yang digunakan adalah research and development dengan pendekatan object-oriented development, yakni bagaimana data dan operasinya yang merupakan kumpulan obyek diorganisasikan dalam satu sistem (Sukamto dan Salahudin, 2014). Selanjutnya website sekolah tersebut digunakan sebagai sarana untuk mengembangkan dan mempublikasikan tulisan siswa. Data dalam PKM ini dilakukan melalui wawancara, kuesioner dan observasi ke lokasi mitra. Kuesioner dilakukan untuk melihat peningkatan pemahaman dan keterampilan siswa sebelum dan sesudah kegiatan pelatihan penulisan ilmiah populer yang dilihat dai hasil pretest dan post-test. Pelaksanaan Kegiatan PKM ini terdiri dari tiga tahapan pelaksanaan, yang dapat dilihat dari skema berikut. Pada Tahap Awal Pelaksanaan dilakukan kegiatan berikut:

- Observasi lokasi mitra, melakukan analisis kebutuhan, dan melakukan pemetaan permasalahan pendidikan di tempat mitra dan prioritas solusi permasalahan yang akan dipecahkan.

- Melakukan penyusunan instrumen pelaksanaan PKM meliputi log book PKM, Lembar Observasi, Daftar tanyaan wawancara untuk setiap kegiatan pelatihan, dan kuesioner di setiap pelatihan.

- Melakukan perancangan web blog sekolah dan melaksanakan pelatihan penulisan ilmiah populer.

- Pemberian Kuesioner

- Penghimpunan data hasil kuesioner, observasi dan wawancara untuk dianalisis.

Dalam pelaksanaan PKM ini, mitra memberikan kontribusi yang signifikan karena mitra bersedia melibatkan seluruh perangkat sekolah mulai dari guru, tenaga pendidikan, dan siswa untuk mengikuti kegiatan PKM.

\section{Hasil dan Pembahasan}

Kegiatan pengabdian ini dimulai dengan melaksanakan pre-test untuk mengungkap tingkat keterampilan menulis siswa. Selanjutnya, pelatihan menulis ilmiah sebanyak 4 kali yang dilaksanakan sebanyak 2 kali sesi daring dan 2 kali sesi tatap muka.

Sesi daring pelaksanaan pelatihan menulis ilmiah popular digelar pada 30-31 Maret 2021. Dalam sesi tersebut, pembicara menyampaikan materi tentang pentingnya menulis, jenis-jenis tulisan, dan media yang dapat digunakan. Sesi pelatihan daring ini diikuti sebanyak 50 siswa SMA N 1 Semaka. Selain sesi daring, pelatihan menulis ilmiah popular juga dilaksanakan secara tatap muka.

Pada saat sesi pelatihan tatap muka, peserta langsung dibimbing untuk merapihkan dan memperbaiki naskah tulisan yang telah mereka susun setelah menerima 2 sesi pelatihan awal. Dua sesi pelatihan menulis yang dilaksanakan secara tatap muka dilangsungkan di SMA N 1 Semaka pada 6-7 April 2021. Setelah pelatihan selesai, 
sebanyak 30 siswa diminta untuk kembali mengisi kuesioner post-test untuk melihat korelasi pelatihan yang diberikan terhadap peningkatan kemampuan menulis mereka.
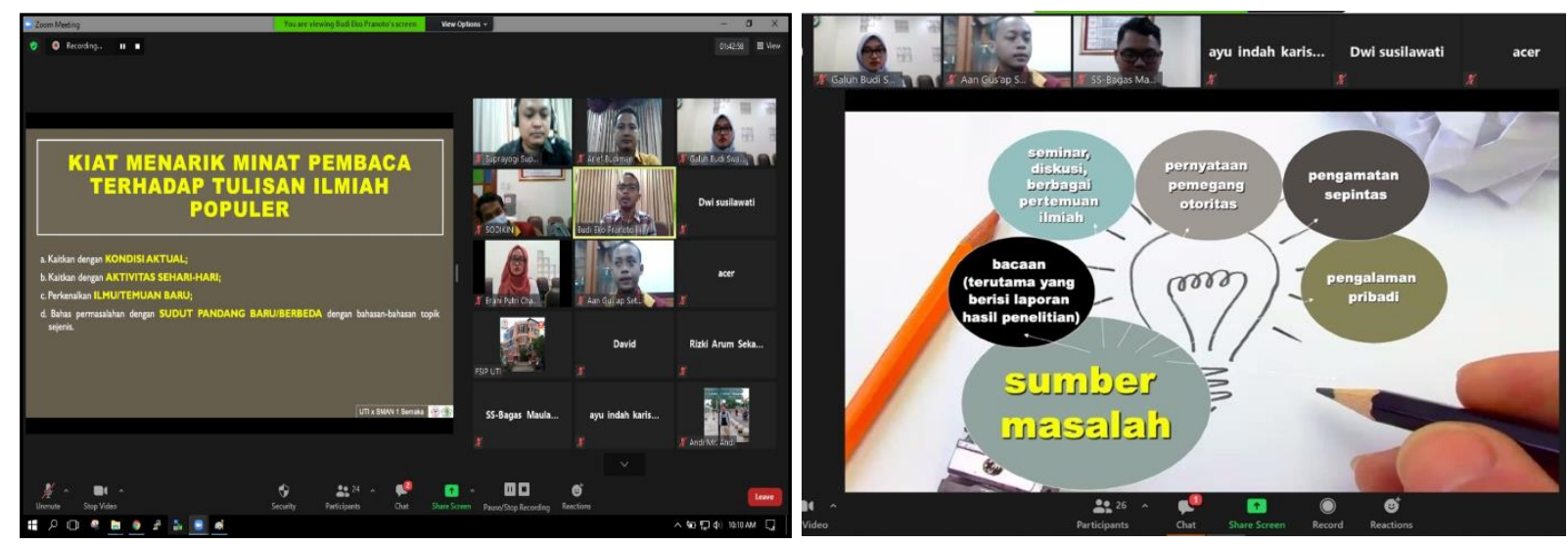

Gambar 2. Pelatihan Menulis Ilmiah Populer (Sesi Daring)

Berdasarkan proses analisis yang telah dilakukan tersebut, diperoleh hasil mengenai peningkatan kemampuan menulis siswa dnegan menggunakan pendekatan CLIL dengan media blog. Terdapat 30 siswa yang dilibatkan dalam eksperimen berikut. Data penelitian diambil dari persepsi siswa sebelum dan sesudah menerima pelatihan menulis. Hasil penelitian tersebut dideskripsikan untuk mengungkapkan gambaran distribusi data. Data diolah dengan menggunakan statistik dasar, yaitu nilai rerata (mean), nilai terbanyak (modus), nilai tengah (median), dan standar deviasi.

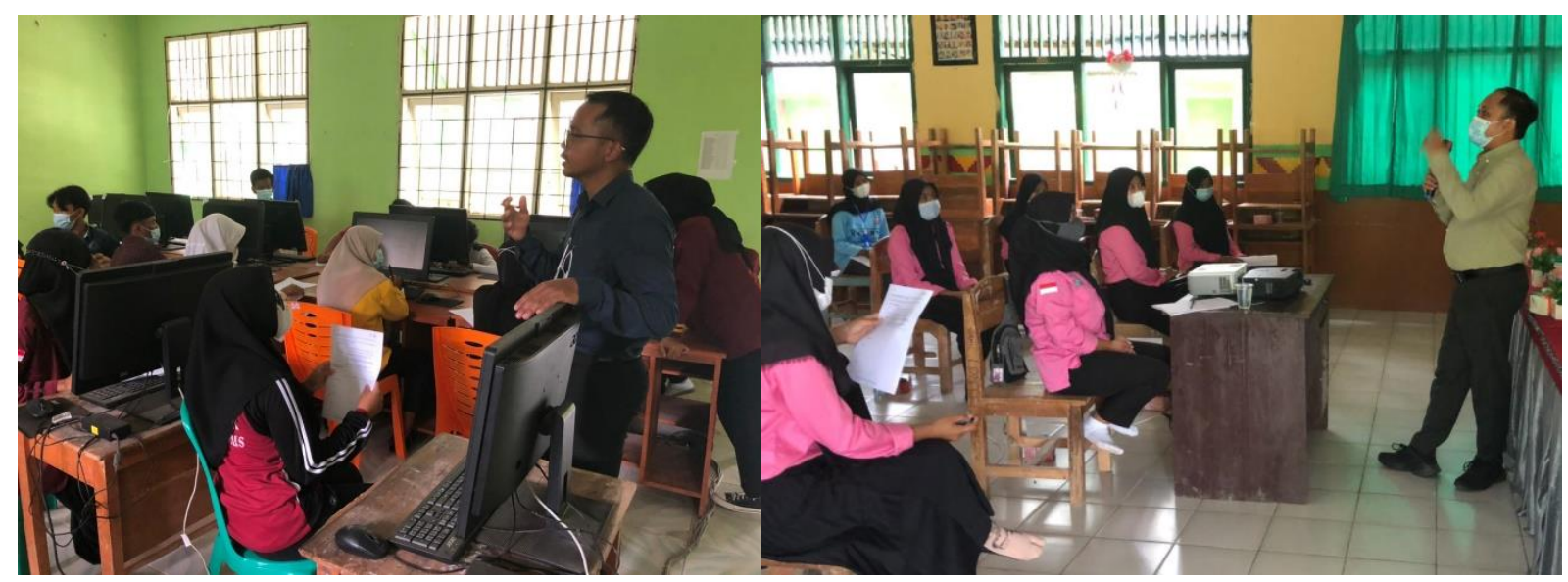

Gambar 3. Pelatihan Menulis Ilmiah Populer (Sesi Luring)

Pada awal penelitian (pre-test), seluruh peserta diberikan kuesioner dengan skala likert (1-10), dengan jumlah sembilan pertanyaan. Delapan pertanyaan tersebut mencakup hal-hal berikut ini: pentingnya menulis dalam media digital, tingkat pemahaman terhadap jenis media digital, jenis-jenis tulisan, langkah-langkah menulis, kaidah menulis, jenis-jenis media, kemampuan menulis, pengetahuan tentang menulis di web, dan kemampuan mengelola web Setelah pelaksanaan pre-test tersebut, seluruh peserta menerima pelatihan menulis digital baik secara teori maupun praktik. 
Tabel 1. Nilai Persepsi Pemelajar Terhadap Kemampuan Menulis Digital

\begin{tabular}{|c|c|c|c|c|}
\hline No. & Pertanyaan & $\begin{array}{l}\text { Pre- } \\
\text { test }\end{array}$ & $\begin{array}{l}\text { Post- } \\
\text { test }\end{array}$ & Gap \\
\hline 1. & $\begin{array}{l}\text { Tingkat pengetahuan Anda tentang pentingnya menulis dengan } \\
\text { menggunakan media digital di era seperti saat ini }\end{array}$ & 5.2 & 6.8 & 1.6 \\
\hline 2. & $\begin{array}{l}\text { Seberapa besar Anda menguasai pembuatan tulisan yang menarik } \\
\text { untuk dipublikasikan dan dibaca secara online? }\end{array}$ & 4.17 & 6.7 & 2.53 \\
\hline 3. & $\begin{array}{l}\text { Tingkat pemahaman Anda tentang jenis-jenis media yang biasa } \\
\text { digunakan dalam menulis dengan menggunakan media digital }\end{array}$ & 5.47 & 7.2 & 1.73 \\
\hline 4. & $\begin{array}{l}\text { Sejauh mana Anda tahu platform/media yang bisa digunakan untuk } \\
\text { menulis konten? }\end{array}$ & 4.27 & 6.9 & 2.63 \\
\hline 5. & $\begin{array}{l}\text { Pemahaman Anda tentang jenis-jenis tulisan yang menarik dan biasa } \\
\text { digunakan untuk menjadi bahan dalam penulisan melalui media } \\
\text { digital }\end{array}$ & 4.94 & 6.8 & 2.26 \\
\hline 6. & $\begin{array}{l}\text { Seberapa paham Anda tentang bagaimana langkah-langkah menulis } \\
\text { di media digital? }\end{array}$ & 4.54 & 7.5 & 2.94 \\
\hline 7. & $\begin{array}{l}\text { Tingkat pemahaman Anda tentang hal yang dibolehkan dan tidak } \\
\text { dibolehkan dalam menulis melalui media digital? }\end{array}$ & 4.44 & 7.1 & 2.66 \\
\hline 8. & $\begin{array}{l}\text { Tingkat keterampilan Anda terhadap cara membuat blog atau micro } \\
\text { blog pribadi yang bisa Anda gunakan untuk mempublikasikan tulisan } \\
\text { Anda? }\end{array}$ & 3.94 & 6.5 & 2.56 \\
\hline 9. & $\begin{array}{l}\text { Tingkat pengetahuan Anda tentang pengelolaan blog atau micro blog } \\
\text { pribadi yang bisa digunakan untuk mempublikasikan tulisan Anda }\end{array}$ & 3.9 & 7.1 & 3.2 \\
\hline
\end{tabular}

Pada Tabel 1, dapat dilihat nilai rerata dari seluruh tanggapan responden terhadap pertanyaan-pertanyaan yang diberikan. Secara kesuluruhan, terjadi peningkatan terhadap persepsi kemampuan menulis seluruh responden yang mengikuti pelatihan menulis digital. Nilai rerata kenaikan adalah sebesar 2.76. Dari delapan poin berikut ini (pentingnya menulis dalam media digital, tingkat pemahaman terhadap jenis media digital, jenis-jenis tulisan, langkah-langkah menulis, kaidah menulis, jenis-jenis media, kemampuan menulis, pengetahuan tentang web, dan kemampuan mengelola web, ditemukan bahwa "kemampuan mengelola web mengalami kenaikan yang paling tinggi di antara poin yang lainnya, yakni sebesar 3.2. Sementara itu, tingkat pengetahuan peserta pelatihan terhadap pentingnya menulis dalam media digital hanya mengalami peningkatan yang kurang signifikan, yakni sebesar 1.6 poin, dikuti dengan peningkatan pemahaman akan jenis-jenis media digital sebesar 1.73 poin. Meskipun demikian, secara keseluruhan, hasil tersebut telah menjawab tujuan penelitian ini yakni peningkatan kemampuan menulis siswa SMA dengan menggunakan media blog. 
1. Pengetahuan Peserta Mengenai Pentingnya Menulis Dalam Media Digital

\begin{tabular}{|c|c|c|c|c|}
\hline No. & Pertanyaan & $\begin{array}{l}\text { Pre- } \\
\text { test }\end{array}$ & $\begin{array}{l}\text { Post- } \\
\text { test }\end{array}$ & Gap \\
\hline 1. & $\begin{array}{l}\text { Tingkat pengetahuan Anda tentang pentingnya menulis dengan } \\
\text { menggunakan media digital di era seperti saat ini }\end{array}$ & 5.2 & 6.8 & 1.6 \\
\hline 2. & $\begin{array}{l}\text { Seberapa besar Anda menguasai pembuatan tulisan yang menarik } \\
\text { untuk dipublikasikan dan dibaca secara online? }\end{array}$ & 4.17 & 6.7 & 2.53 \\
\hline
\end{tabular}

Hal yang melatari diadakannya program pengabdian masyarakat di SMA N 1 Semaka salah satunya adalah kurangnya paparan peserta terhadap informasi mengenai pentingnya menulis dan pemanfaatan media digital untuk mempublikasikan tulisan tersebut (informasi dari pengajar). Kurangnya paparan tersebut juga dikonfirmasi oleh hasil pre-test. Hasil pre-test menunjukkan bahwa rata-rata nilai tingkat pengetahuan peserta mengenai pentingnya menulis dalam media digital adalah 5.2 poin (skala 1-10). Dalam pelatihan menulis digital yang diberikan, peserta menerima materi mengenai peranan kemampuan menulis di era sekarang. Responden penelitian ini, setelah mendapatkan pelatihan, menunjukkan peningkatan sebesar 1.6 poin; bukan merupakan peningkatan yang signifikan, namun menilik skor pre-test yang didapat, temuan ini menunjukkan adanya perbaikan. Jika dibandingkan lebih detil, lebih dari 50\% peserta memiliki nilai $<5$, dan jika dibandingkan dengan nilai post-test, lebih dari $50 \%$ peserta mendapatkan nilai $>7$. Hal ini menunjukkan peningkatan yang signifikan yang cukup kentara.

Pada komponen selanjutnya, ditemukan bahwa siswa juga memiliki tingkat penguasaan akan penyusunan tulisan yang menarik. Rata-rata nilai pre-test siswa adalah 4.17. Angka tersebut merupakan salah satu nilai yang rendah dibandingkan dengan nilai pre-test komponen lainnya. Setelah pelaksanaan pelatihan menulis, diperoleh peningkatan sebesar 2.53 poin pada nilai post-test (6.7). Temuan ini menunjukkan adanya perbaikan yang signifikan.

2. Pemahaman Peserta Tentang Jenis-jenis Media Digital dan Penunjangnya

\begin{tabular}{|c|c|c|c|c|}
\hline No. & Pertanyaan & $\begin{array}{l}\text { Pre- } \\
\text { test }\end{array}$ & $\begin{array}{l}\text { Post- } \\
\text { test }\end{array}$ & Gap \\
\hline 3. & $\begin{array}{l}\text { Tingkat pemahaman Anda tentang jenis-jenis media yang biasa } \\
\text { digunakan dalam menulis dengan menggunakan media digital }\end{array}$ & 5.47 & 7.2 & 1.73 \\
\hline 4. & $\begin{array}{l}\text { Sejauh mana Anda tahu platform/media yang bisa digunakan untuk } \\
\text { menulis konten? }\end{array}$ & 4.27 & 6.9 & 2.63 \\
\hline
\end{tabular}

Lokasi sekolah yang berada di pinggiran daerah kabupaten dengan akses yang belum sepenuhnya memadai menyebabkan terbatasnya paparan dengan keterbaruan mediamedia digital terkini yang dapat digunakan untuk menulis. Pada aspek ini, peningkatan yang dicapai juga tidak begitu tinggi, hanya sebesar 1.73 poin. Namun, nilai post-test yang diperoleh yang mencapai angka 7.2 merupakan pencapaian sebuah perbaikan yang baik 
karena mendekati angka post-test tertinggi dari 9 aspek yang dikaji dalam penelitian ini. Pencapaian ini merupakan hasil dari pelatihan yang salah satu isinya adalah mengenai rangkaian media yang dapat digunakan untuk mempublikasikan tulisan. Hasil ini juga diikuti dengan rendahnya pengetahuan mereka terhadap ketersedian platform yang dapat digunakan untuk menulis konten. Akan tetapi, penggunaan blog berkorelasi signifikan terhadap peningkatan komponen tersebut, yakni sebesar 2.63 .

3. Pemahaman Peserta Tentang Jenis, Langkah, dan Kaidah Penulisan

No. Pertanyaan

Pre- Post- Gap

test test

5. Pemahaman Anda tentang jenis-jenis tulisan yang menarik dan biasa digunakan untuk menjadi bahan dalam penulisan melalui media $4.94 \quad 6.8$ 2.26 digital

6. Seberapa paham Anda tentang bagaimana langkah-langkah menulis di media digital? dibolehkan dalam menulis melalui media digital?

Hasil pre-test menunjukkan bahwa mayoritas responden memiliki pemahaman yang rendah akan jenis-jenis tulisan dan topik menarik yang dapat digunakan dalam penulisan melalui media digital. Rata-rata nilai yang diperoleh adalah 4.94. Rendahnya pemahaman responden juga dikonfirmasi dengan ketidaktahuan mereka dengan jenis-jenis tulisan yang disampaikan saat berlangsungnya pelatihan. Meskipun demikian, diperoleh peningkatan yang cukup baik, yakni sebesar 2.26 poin. Peningkatan tersebut menunjukkan ada pengaruh dari pelatihan terhadap kemampuan siswa.

Lebih dari pada itu, kondisi siswa, yang ditampilkan pada aspek 1 dan 2, juga berkorelasi dengan kondisi yang tercermin pada aspek pemahaman siswa mengenai langkah-langkah menulis. Pada aspek ini, hasil pre-test menunjukkan rendahnya (nilai rata-rata 4.54) pemahaman siswa mengenai langkah-langkah menulis, terlebih menulis di media digital. Saat pelatihan berlangsung, banyak siswa yang mengaku belum pernah menulis cerita pendek maupun panjang. Umumnya mereka hanya sering menulis untuk keperluan status ataupun keterangan gambar yang mereka unggah di akun media sosial mereka. Meskipun demikian, justru hasil pengaruh pelatihan tampak kentara, yakni berupa peningkatan nilai post-test menjadi 7.5. Kenaikan 2.94 merupakan kenaikan tertinggi kedua dari keseluruhan aspek yang dilatih.

Peningkatan kemampuan siswa untuk memahami langkah-langkah menulis juga diikuti dengan peningkatan pemahaman mereka terhadap kaidah penulisan digital. Meski nilai pre-test yang cukup kecil (4.44), hasil post-test mencapai 7.1 (kenaikan sebesar 2.66). Peningkatan yang dicapai atas 3 komponen ini sangat baik dan merata yakin $>2$. Hal ini merupakan perbaikan yang bai atas kemampuan menulis siswa SMA N 1 Semaka. 
Keterbatasan teknologi yang ada di lingkungan siswa berpengaruh pada rendahnya keterampilan mereka dalam membuat dan mengelola web. Hasil web juga menunjukkan nilai yang terendah dibandingkan dengan komponen-komponen yang dilatih lainnya, yakni hanya sebesar 3.94 dan 3.9. Rendahnya nilai pre-test juga didukung oleh kebingugan yang muncul saat siswa diperkenalkan dengan web sebagai salah satu media tulis digital. Namun, justru pada aspek inilah diperolah kenaikan sebesar 3.2. Peningkatan ini adalah yang tertinggi dibandingkan dengan komponen yang dilatih lainnya. Peningkatan tersebut menunjukkan korelasi yang signifikan antara pelatihan menulis dan peningkatan kemampuan menulis siswa.

4. Keterampirlan Peserta untuk Membuat web

\begin{tabular}{lllll}
\hline No. Pertanyaan & $\begin{array}{c}\text { Pre- } \\
\text { test }\end{array}$ & $\begin{array}{c}\text { Post- } \\
\text { test }\end{array}$ & Gap \\
\hline $\begin{array}{l}\text { 8. } \quad \begin{array}{l}\text { Tingkat keterampilan Anda terhadap cara membuat web pribadi yang } \\
\text { bisa Anda gunakan untuk mempublikasikan tulisan Anda? }\end{array} \\
\quad 3.94\end{array}$ & 6.5 & 2.56 \\
$\begin{array}{l}\text { 9ingkat pengetahuan Anda tentang pengelolaan web pribadi yang } \\
\text { bisa digunakan untuk mempublikasikan tulisan Anda }\end{array}$ & 3.9 & 7.1 & 3.2 \\
\hline
\end{tabular}

Terkait dengan penjabaran pada bagian hasil temuan di atas, peneliti menyimpulkan beberapa temuan penting. Hasil dan temuan dalam pengabdian ini dapat dibandingkan dengan hasil penelitian sebelumnya yang diulas di bagian pendahuluan. Perbandingan ini sejatinya dibuat untuk memberikan wawasan tentang peranan web sekolah terhadap peningkatan kemampuan menulis ilmiah populer siswa. Hasil analisis di atas mengkonfirmasi temuan Ansoriyah (2020:53) yang mengungkapkan bahawa pengombinasian pendekatan CLIL dengan web sekolah dapat meningkatkan kemampuan menulis ilmiah popular siswa. Namun, nilai rerata yang diperoleh lebih rendah dari pada yang ditemukan pada Ansoriyah (2020). Hal ini menunjukkan adanya perbedaan latar belakang responden yang berbeda. Selanjutnya, jika dibandingkan dengan hasil penelitian Indawati dan Sumardi (2019), temuan dalam analisis di atas ini juga mendukung temuan tersebut, bahwa siswa yang mendapatkan paparan terhadap penggunaan media web mengalami peningkatan kemampuan (ditunjukkan dengan peningkatan nilai rerata menjadi 7). Sementara itu, jika dibandingkan dengan Situmorang (2018), langkah-langkah yang ditempuh memang berbeda, akan tetapi hasil yang ditemukan saling mengonfirmasi. Pemanfaatan web sekolah bekorelasi positif terhadap peningkatan keterampilan menulis siswa.

\section{Kesimpulan}

Hasil yang didapatkan dari proses analisis atas nilai pre-test dan post-test pada siswa mengungkapkan adanya peningkatan keterampilan siswa dalam menulis artikel ilmiah populer. Keseluruhan komponen yang diujikan dalam pengabdian ini seluruhnya mengalami peningkatan (perbaikan). Hasil ini tentu menjadi temuan yang memenuhi tujuan dari diadakannya pengabdian ini. Kondisi awal peserta memiliki pengaruh yang besar terhadap peningkatan yang dicapai. Lokasi mitra yang berada di daerah pelosok 
dengan paparan teknologi terkini yang minimal, menyebabkan perbaikan yang minimal $(<2)$. Akan tetapi secara keseluruhan, tingkat perbaikan yang dicapai seluruhnya signifikan.

\section{Ucapan Terimakasih}

Pengabdian kepada masyarakat ini merupakan Hibah Internal Universitas Teknokrat Indonesia dengan Surat Perjanjian Penugasan Pelaksanaan Pengabdian kepada Masyarakat Nomor 019/UTI/LPPM/E.1.8/II/2021. Ucapan terima kasih ditujukan kepada Universitas Teknokrat Indonesia dan LPPM Universitas Teknokrat Indonesia atas dukungannya sehingga kegiatan ini dapat berlangsung secara baik dan lancar.

\section{Referensi}

Abbas, S. (2006). Pembelajaran Bahasa Indonesia Yang Efektif Di Sekolah Dasar. Jakarta: Dirjen Dikti Depdiknas.

Ansoriyah, S. (2020). Pengaruh Pendekatan CLIL dengan Media Blog Terhadap Keterampila Menulis Artikel Ilmiah Sebagai Pengembangan Bahasa. Jurnal Pendidikan Bahasa dan Sastra Indonesia, 5(1), 48-55.

Chandra, H. A. (2014). Upaya Meningkatkan Kemampuan Menulis pada Mata Pelajaran Bahasa Indonesia dengan Menggunakan Model Pembelajaran Scramble pada Siswa Kelas II SD Negeri 1 Wonosari Sadang Kebumen. Jurnal PGSD Indonesia PGRI Yogtakarta, 1(2).

Cresswell, J. W. (2015). Penelitian Kualitatif dan Desain Riset. Yogyakarta: Pustaka Pelajar. Faharani, A. A. K., \& Abdollahi, Z. (2018). Incorporating Humor to Develop EFL Learner's Speaking Ability and Willingnes to Communicate. Journal of Language Teaching and Research, 9(1), 205-211.

Gusti, Y. (2014). Meningkatkan Kemampuan Menulis Kreatif Siswa Melalui Pendekatan Whole Languange dengan Teknik Menulis Jurnal. Jurnal Perspektif IImu Pendidikan UNJ, 28(1).

Hibatullah, O. F., \& Ardillah, Q.F. (2019). “Give me a joke, please!”: Creating a Fun Learning by Teacher's Jokes. PEOPLE: International Journal of Social Sciences, 5(2), 948-958.

Iskandarwassid, \& Ristianti, I. (2010). Peningkatan kemampuan menulis narasi melalui model pembelajaran teknik visual-auditif-taktil. Jurnal Penelitian Ilmu Pendidikan, 11(1), 75-99.

Indawati, N., \& Aida, S. (2019). Pengaruh Media Blog Terhadap Keterampilan Menulis Teks Negoisasi. Prosiding Seminar Nasional Pendidikan. Jakarta. Hal. 65-75.

Moleong, L. J. (2009). Metode Penelitian Kualitatif. Bandung: Remaja Rosdakarya. Nugroho, I. R. (2014). Menjadi Penulis Kreatif. Jakarta: Notebook.

Pranoto, B. E., \& Suprayogi. (2020). Incorporating 9GAG Memes to Develop EFL Learners' Speaking Ability and Willingness to Communicate. IJEE (Indonesian Journal of English Education), 7(2), 130-144.

Sidiq, Sahabudin., Wahyudi, B.P., Anindita, Damayanti. (2013). Pelatihan Menulis Kreatif untuk Mengembangkan Potensi dan Kreativitas Anak. Jurnal Inovasi dan Kewirausahaan, 2(3), 219-223. 
Vol. 2, No. 3, Agustus 2021

ISSN 2721-4834

Sari, dkk. (2017). Pengembangan Media Blog dalam Pembelajaran Menulis Teks Anekdot pada Siswa Kelas X SMA. Jurnal Ilmu Budaya, 1(4), 317-330.

Situmorang, N. M. Y. (2018). Meningkatkan Kemampuan Menulis Siswa Melalui Teknik Guiding Questions. Journal of Education Action Research, 2(2), 165-171.

Subandi, A., Satrijono, H., \& Suhartiningsih, S. (2014). Meningkatkan kemampuan menulis narasi sugestif dengan menggunakan media gambar seri siswa kelas V SDN arjasa jember. Jurnal Edukasi, 1(1), 1-4.

Sukamto, R. A., \& Salahuddin, M. (2014). Rekayasa Perangkat Lunak Terstruktur dan Berorientasi Objek. Bandung: Informatika.

Suprayogi, S., \& Pranoto, B. E. (2020). The Implementation of Virtual Exhibition Project in English for Tourism Class for University Students. Academic Journal Perspective, 8(2), 87-97.

Zulkarnaini. (2011). Model Kooperatif Tipe Think Talk Write (TTW) untuk Meningkatkan Kemampuan Menulis Karangan Deskripsi dan Berpikir Kritis. Jurnal.Upi.Edu, 11(2), 144-153. 